\title{
Diversity and distribution of Chironomidae (Insecta: Diptera) of protected areas in North Tunisia
}

\author{
S. Boulaaba ${ }^{(1), \star}$, S. Zrelli ${ }^{(1)}$, M. Płóciennik ${ }^{(2)}$, M. Boumaiza ${ }^{(1)}$ \\ Received October 3, 2014 \\ Accepted October 6, 2014
}

Key-words:

Diptera, Chironomidae, wadi, biodiversity, Tunisia

\section{ABSTRACT}

In North Africa seasonal streams called wadi are an unique habitats with serve hydrological and thermal regime. Non-biting midges take an important part of freshwater biodiversity in North Africa. We present new data on the distribution and diversity of Chironomidae in North Tunisia. Larvae, pupal exuviae and adult males of chironomids were collected from a various freshwater ecosystems from May 2005 till April 2006. The aim of this study was to recognize the pattern of midge diversity in North Tunisia to estimate ecological value of running waters in the region. In total, 79 taxa were identified. Nearly all of the taxa were typical representatives of the Palaearctic and Mediterranean complexes. The majority of the investigated sites belonged to the protected areas in North Tunisia, such as the Ichkeul National Park, the Kroumerie Mountains and the El Feija National Park, part of the Intercontinental Reserve of the Mediterranean Biosphere. Altitudinal zonation of the communities composition was found in the lowland (<250 $\mathrm{m}$ a.s.I.) and upland zone (>250 m a.s.I.) with maximum of $760 \mathrm{~m}$. Whereas among the data 39 species are recorded from Tunisia for the first time, the species richness of Chironomidae is higher than previously estimated.

\section{RÉSUMÉ}

\section{Diversité et distribution des Chironomidae (Insecta, Diptera) au Nord de la Tunisie}

Mots-clés:
Diptera,
Chironomidae,
oueds,
la biodiversité,
la Tunisie

En Afrique du Nord, les cours d'eau saisonniers (Wadis) sont les habitats uniques qui servent les régimes hydrologiques et thermaux. Les chironomidae prennent une part importante dans la biodiversité des eaux douces d'Afrique du Nord. Nous présentons de nouvelles données sur la répartition et la diversité des Chironomidae au Nord de la Tunisie. Les larves, les pupes, les exuvies et les mâles adultes de chironomes sont recueillies dans divers wadis de mai 2005 à avril 2006. L'objectif de cette étude est de reconnaître le modèle de diversité de cette famille dans le Nord de la Tunisie pour estimer sa valeur écologique dans la région. Au total, 79 taxons ont été identifiés. La plupart des taxons sont des représentants typiquement paléarctique et méditerranéens. Les sites étudiés appartenaient aux réserves dans le Nord de la Tunisie : le parc d'Ichkeul, les montagnes de Kroumirie et le Parc El Feij. La zonation altitudinale de la composition des communautés a été trouvé dans la plaine $(<250 \mathrm{~m})$ et dans la zone de montagne $(>250 \mathrm{~m})$ avec un maximum de $760 \mathrm{~m}$. Considérant qu'avec 39 espèces de Chironomidae enregistrées pour la première fois en Tunisie, la richesse spécifique est plus élevée que dans les estimations précédentes. 


\section{INTRODUCTION}

In the Mediterranean Region, freshwater biological communities and their ecological traits are constrained by great seasonal variability of temperature and rainfall (Bonada et al., 2007; Chaib et al., 2011). The hydrological conditions, strongly variant among seasons with many rivers and streams (known in North Africa as wadi) having intermittent flows, cause a strong shift between lotic and lentic conditions through the year (Pinto, 1994; Morais et al., 2004).

Up till now, North African streams or wadis have been scantily studied; particularly their ecological aspects are scarcely known (e.g. Lounaci et al., 2000a; Chaib et al., 2011). Nevertheless, some studies on benthic communities have been carried out recently (e.g. Lounaci et al., 2000b; Arab et al., 2004; Belaidi et al., 2004; Zrelli et al., 2011; Touaylia et al., 2011). New data show certain peculiar features of Northern African lotic ecosystems: wadis are strongly influenced by the unique Mediterranean climate (i.e. extreme temperature values during summer and short extreme flooding events in winter, followed by long periods of drought). As a result, fauna of wadi is relatively poor compared to continental European Mediterranean regions (Giudicelli et al., 1985; Lounaci et al., 2000a).

The chironomid fauna of North-West Africa has been relatively well recognized in Marocco (Kettani et al., 2001; Kettani and Langton, 2011), Algeria (Moubayed et al., 2007; Chaib et al., 2011, 2013) while much less in Tunisia (Boumaiza, 1988). All faunistic data on non-biting midges in Tunisia have been summarized in the checklist of Chironomidae species recorded in this country (Boumaiza and Laville, 1998). Currently, there is available only a faunistic list of taxa from the country. That is why there is a need for a broad investigation which would explain not only the faunistic connection of Tunisian chironomid fauna, but also the ecological relation between larval communities and the environment. As wadis are widely spread, flowing water habitats in North Africa, the midge diversity strongly depends on their existence. North Tunisia is highly diversified due to geographical conditions - from high mountains to lowland deserts, which results in climatic variability in this region. We wish to present new data on Chironomidae of North Tunisia with many new species recorded in the country. The preliminary analysis of non-biting midge biodiversity and the general geographical pattern of its distribution are also presented.

\section{STUDY AREA}

North Tunisia includes two mountain chains: the Tell (Kroumir and Mogods Mountains) and the Dorsal (Châambi Mountains) (Ben Ayed, 1993).

The humid area is limited to the Kroumir Mountains, leading to the development of a dense forest (Zielhofer and Faust, 2008). Annual rainfall increases from the north to the south with most rains during winter; some northern regions get an annual rainfall average of more than $1300 \mathrm{~mm}$ per year (e.g.: the northwestern region of Tabarka). In contrast, the regions in the far south receive less than $100 \mathrm{~mm}$ of rain per year (Ben Jemaa et al., 1998). Water bodies are unevenly distributed within the country, with the northern part holding $60 \%$ of the total water resources (Houcine et al., 1999). The precipitation decreases from the north to the south, with most of the rainfall in winter (Ben Jemaa et al., 1998). Water resources are unevenly distributed within the country; the northern part, covering an area of only $17 \%$ of the territory, has $60 \%$ of the total water resources (Houcine et al., 1999).

According to the subdivision of hydrographic nets in the northern region of Tunisia by the Commissariat Régional au Développement Agricole (CRDA), the total wadi system belongs to three different basins (Figure 1): (i) The North-West Basin is primarily agricultural land with an area of $6512 \mathrm{~km}^{2}$. This basin is also full of large water reservoirs with 366 million $\mathrm{m}^{3}$ (21 dams and 39 lakes) in the extreme North-West of Tunisia; it is distinguished by the wettest climate in the country with annual precipitation reaching $1000 \mathrm{~mm}$ on the coast (near Tabarka $1050 \mathrm{~mm}$ ) and more than $1500 \mathrm{~mm}$ in Ain Draham. (ii) The Basin of Beja-Ichkeul, situated in the extreme north of Tunisia and forming the most advanced point of Africa, with an area of $7490 \mathrm{~km}^{2}$. It has two types of climate: a humid climate with rainfall of $600 \mathrm{~mm}$ to $1200 \mathrm{~mm}$ (north); 


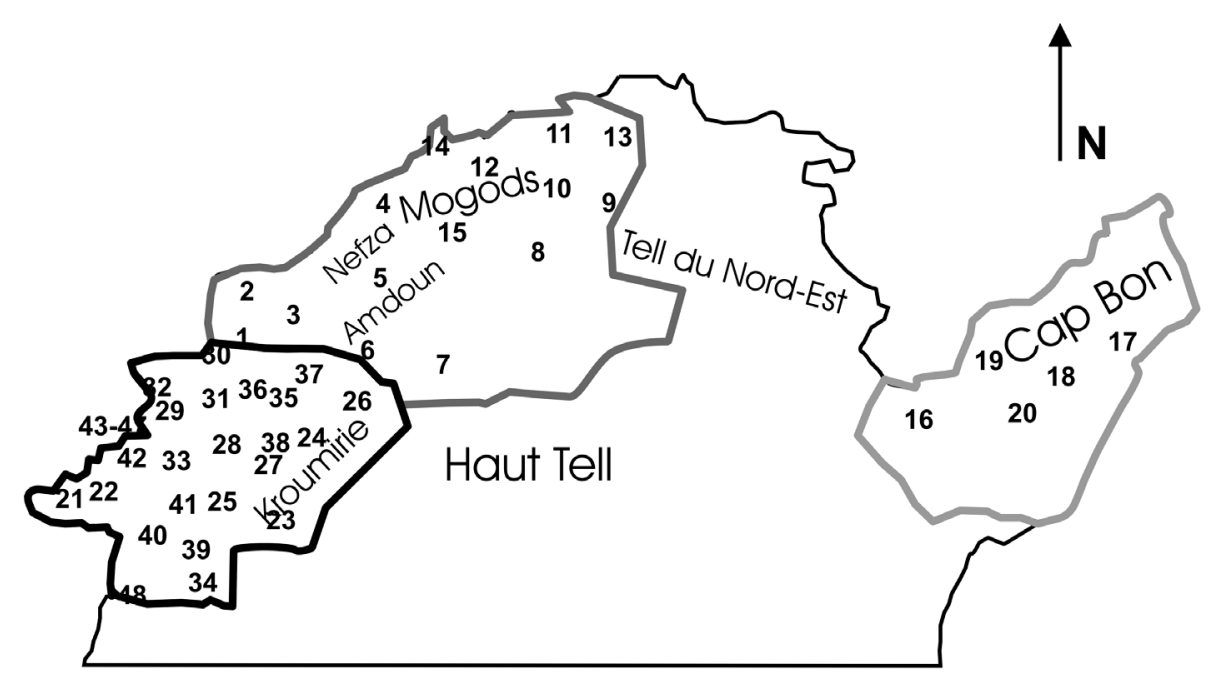

The North-West Basin The Basin Beja-Ichkeul The North-Eastern Basin

Figure 1

Map of the study area. Numbers of study sites according to Appendix I.

a relatively dry climate with precipitation of 350-450 $\mathrm{mm}$ (south); and iii) the North-Eastern Basin in the Cap Bon region, covering an area of $6570 \mathrm{~km}^{2}$, with an annual precipitation of $750 \mathrm{~mm}$.

\section{MATERIALS AND METHODS}

Forty-eight sampling sites were chosen among the three basin area on the basis of water permanence, with samples taken monthly, from May 2005 till April 2006. The study sites were distributed over three major watersheds. The positions, coordinates and altitudes of the sampling sites are indicated in Figure 1 and Appendix I chironomid larvae and pupae exuviae were collected with a Surber net $(300 \mu \mathrm{m}$ mesh size, $50 \mathrm{~cm}$ width) (Surber, 1937). Ten samples were collected opposite to the current along the sampling station, in the middle of the current and near the banks, then merged together for the statistical analysis. It was also randomly collected larave from submerged stones with a total surface area of $1 \mathrm{~m}^{2}$ at each site. Adults were collected with a entomological net near a wadi banks. The material was first preserved in $10 \%$ formaldehyde, and later transferred to $70 \%$ ethyl alcohol for sorting and final conservation. The species identification was based on imagines, prepupae, where the pupal characters were morphologically visible, and larvae. The keys for larvae determination were used (Brooks et al., 2007; Epler, 2001; Ferrarese, 1983; Ferrarese and Rossaro, 1981; Nocentini, 1985; Rossaro, 1982; Wiederholm, 1983), along with the keys for Palaearctic pupal exuviae (Langton, 1984; Langton and Visser, 2003; Wilson and Ruse, 2005) and for adult males (Langton and Pinder, 2007). There are no keys for Chironomidae published from the Tunisian region. Besides Langton and Visser (2003), the above-mentioned keys are from Europe, the Western Holarctic, the North Mediterranean or the whole Holarctic region and allow to identify chironomids only to genera. Thus, most of the material was identified only to the genus level or morphotypes and to the species level when possible. The community analysis was done with PRIMER 5 software. To examine faunistic differences between the studied wadis and basins, the data were transformed to the presence-absence matrix. The within sites Bray-Curtis similarity index 93 was calculated. The SIMPER analysis was performed to reveal characteristic taxa for the two main community types ( $A$ and $B$ ) separated with NonMetric Multidimensional Scaling (NMDS). To estimate how the measured diversity reflects the real species richness in the region, the rarefaction curve was counted for all the samples with PAST software. 


\section{Table I}

Comparison of the number of Chironomidae species recorded in North Tunisia with the work of Boumaiza and Laville (1988).

\begin{tabular}{|l|c|c|}
\hline Subfamily & Boumaiza and Laville, & This study \\
\hline Diamesinae & 1988 & 3 \\
\hline Prodiamasinae & 1 & 0 \\
\hline Tanypodinae & 8 & 12 \\
\hline Orthocladiinae & 27 & 26 \\
\hline Chironominae & 33 & 38 \\
\hline Total & 70 & 79 \\
\hline
\end{tabular}

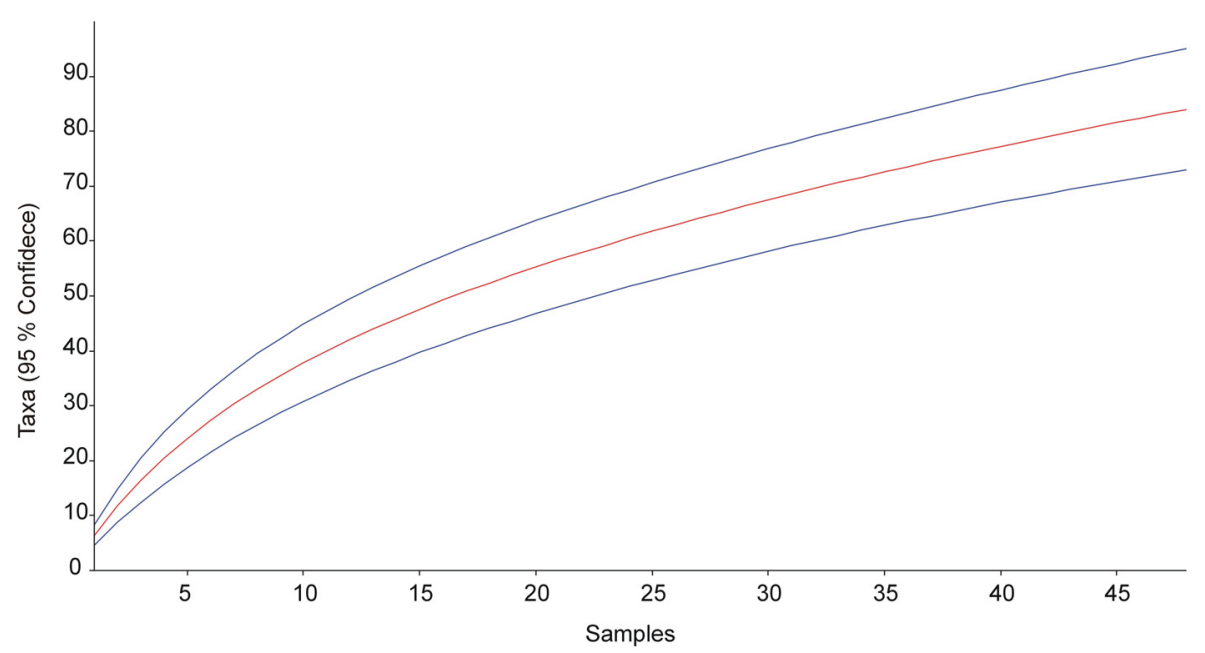

Figure 2

Rarefaction curve of the presented new data on Chironomidae occurrence in North Tunisia.

\section{RESULTS}

\section{> NEW FAUNISTIC DATA}

Appendix II presents a list of the Chironomidae recorded from the 48 sites in the study area. These new data increase the number of species recorded in North Tunisia to 117. Table I presents the comparison of Boumaiza and Laville (1988) and our data. Both studies show similar proportions in the number of species among subfamilies with strong dominance of Chironominae. This research adds 39 new species of Chironomidae from Tunisia not recorded earlier (Boumaiza and Laville, 1988). As more than $49 \%$ of all the taxa recorded in this study are new for the study area and the number of recorded species quickly increase with any new data added (Figure 2), the present investigation predicts also the high potential of the Chironomidae diversity in the region.

\section{> GEOGRAPHICAL PATTERN}

Among the 79 identified taxa, 21 species (27\%) are reported from the North-Eastern Basin, including 7 species so far recorded in Tunisia only in this region. In the Basin of Beja Ichkeul, 51 species (64\%) were found with 15 species recorded only in this area of Tunisia, 58 species $(73 \%)$ were identified in the North West Basin with 24 taxa found only in this part of the country.

The number of species varies between the three regions. The highest number of taxa in the North-Eastern Basin was found in the Chiba wadi (st. 18) (9 species). In the Basin of Béja-Ichkeul, the number of recorded taxa exceed 10 only in the Tetria (st. 1), Sejenane (st. 12) 


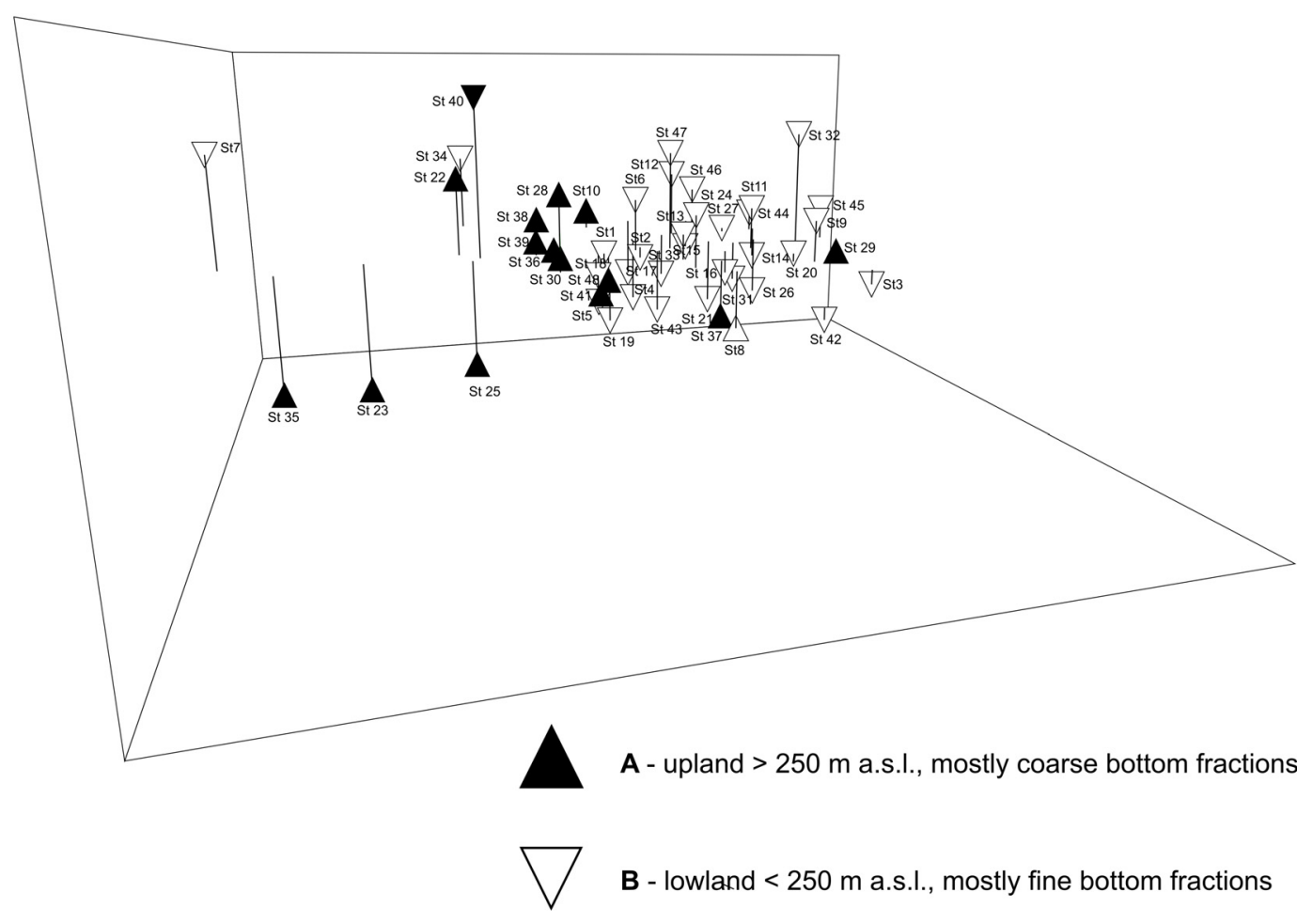

Figure 3

Results of NMDS analysis.

and Kloufi (st. 13) (15, 13 and 17 species respectively). The highest number of taxa was found in 117 the North-West Basin in the Ennour wadi (st. 39) (26) and the wadis of Sallen (st. 48) and Mrig (st. 41) (10 and 9 respectively). The NMDS analysis (Figure 3 ) has indicated that there are two main types of communities in North Tunisia. Community type A dominates in upland areas from ca. $250 \mathrm{~m}$ a.s.l. to more than $750 \mathrm{~m}$ a.s.l. on coarse sediments (frequently rock blocks and pebbles). This type is more diverse, as the sites differ in the fauna of chironomids more strongly than in type B. Rheocricotopus effusus, Larsia atrocincta, Zavrelimyia nubila and Procladius spp. are more frequent in mountain and foothill streams (Table II). According to Moller Pillot (2009) and Moller Pillot and Klink (2003), R. effusus inhabits small, fast flowing streams of relatively high trophy, with good oxygen conditions, and often occurs on the hard bottom. Community type B (Figure 3 ) dominates in lowland areas up to $250 \mathrm{~m}$ a.s.I., frequently on the soft bottom with fine mineral fractions. Fauna of the North Tunisia lowlands is less diverse. This group includes taxa more tolerant to oxygen deficiency. They are found mainly in small streams with a strong current (Orthocladius frigidus, Macropelopia nebulosa), but present also in larger, slow-flowing and stagnant waters (Polypedilum nubeculosum-type, Chironomus plumosus) (Table II) (Vallenduuk and Moller Pillot, 2007; Moller Pillot, 2009; the authors' personal observations).

\section{DISCUSSION}

The midge communities in North Algeria also differ according to the sediment structure. Chaib et al. (2013) have pointed out that in the North African water systems, hard substrate (e.g. cobbles) offers suitable conditions (interstitial space to survive a low water level and accumulate organic matter, a substructure for peryphiton) for midge larvae. In the Algerian river systems, chironomid fauna is more diverse in hard bottomed streams. In wadis, where fine 
Table II

Results of SIMPER analysis.

Group A

Average similarity: 14.84

\begin{tabular}{|l|c|c|c|c|c|}
\hline Species & Av. Abund & Av. Sim & Sim/SD & Contrib \% & Cum. \% \\
\hline Rheocricotopus effusus (Walker, 1856) & 1.93 & 2.73 & 0.43 & 18.41 & 18.41 \\
\hline Larsia atrocincta (Goetghebuer, 1942) & 1.47 & 2.68 & 0.30 & 18.06 & 36.47 \\
\hline Procladius sp & 4.33 & 2.32 & 0.45 & 15.64 & 52.11 \\
\hline Zavrelimyia nubila (Meigen, 1830) & 2.0 & 1.58 & 0.52 & 10.69 & 62.80 \\
\hline Orthocladius frigidus (Zetterstedt, 1838) & 0.53 & 0.79 & 0.21 & 5.32 & 68.12 \\
\hline Phaenopsectra flavipes (Meigen, 1818) & 1.53 & 0.74 & 0.24 & 4.99 & 73.11 \\
\hline Ablabesmyia Iongistyla (Fittkau, 1962) & 0.53 & 0.74 & 0.21 & 4.98 & 78.08 \\
\hline Chironomus plumosus (Linné, 1758) & 0.40 & 0.56 & 0.22 & 3.79 & 81.87 \\
\hline Rheopelopia ornata (Meigen, 1838) & 0.33 & 0.43 & 0.17 & 2.87 & 84.74 \\
\hline Stictochironomus maculipennis (Meigen, 1818) & 0.60 & 0.40 & 0.14 & 2.70 & 87.44 \\
\hline Micropsectra atrofasciata (Kieffer, 1911) & 0.67 & 0.35 & 0.17 & 2.38 & 89.82 \\
\hline Cryptochironomus sp. & 0.40 & 0.32 & 0.10 & 2.14 & 91.96 \\
\hline
\end{tabular}

Group B

Average similarity: 16.65

\begin{tabular}{|l|c|c|c|c|c|}
\hline Species & Av. Abund & Av. Sim & Sim/SD & Contrib \% & Cum. \% \\
\hline Procladius sp. & 2.39 & 4.36 & 0.50 & 26.19 & 26.19 \\
\hline Chironomus plumosus (Linné, 1758) & 1.18 & 3.29 & 0.51 & 19.76 & 45.96 \\
\hline Orthocladius frigidus (Zetterstedt, 1838) & 0.61 & 1.54 & 0.32 & 9.23 & 55.19 \\
\hline Polypedilum nubeculosum-type & 3.70 & 1.33 & 0.29 & 7.99 & 63.18 \\
\hline Macropelopia sp. (Meigen, 1818) & 0.97 & 1.18 & 0.28 & 7.09 & 70.28 \\
\hline Chironomus salinarius (Kieffer, 1915) & 0.58 & 0.62 & 0.22 & 3.75 & 74.03 \\
\hline Cryptochironomus sp. & 1.52 & 0.46 & 0.17 & 2.76 & 76.79 \\
\hline Natarsia sp. (Meigen, 1804) & 0.58 & 0.41 & 0.16 & 2.46 & 79.25 \\
\hline Dicrotendipes nervosus (Staeger, 1839) & 0.39 & 0.40 & 0.16 & 2.40 & 81.65 \\
\hline Rheocricotopus effusus (Walker, 1856) & 1.15 & 0.39 & 0.16 & 2.33 & 83.98 \\
\hline Tvetenia calvescens (Edwards 1929) & 0.58 & 0.35 & 0.16 & 2.12 & 86.10 \\
\hline Procladius choerus (Meigen, 1804) & 0.36 & 0.31 & 0.14 & 1.86 & 87.96 \\
\hline Einfeldia pagana (Meigen, 1838) & 0.24 & 0.29 & 0.14 & 1.75 & 89.71 \\
\hline Phaenopsectra flavipes (Meigen, 1818) & 0.67 & 0.23 & 0.14 & 1.38 & 91.09 \\
\hline
\end{tabular}

Groups B \& A

Average dissimilarity $=87.43$

SIMPER

Similarity percentages - species contributions

Parameters

Transform: presence/absence

Cut off for low contributions: $90.00 \%$

Factor groups

A - upland $>250 \mathrm{~m}$ a.s.I., mostly coarse bottom fractions

$B$ - lowland $\leqslant 250 \mathrm{~m}$ a.s.l., mostly fine bottom fractions

and ultrafine mineral fractions dominate, the current is usually strong while a compacted bottom fraction does not provide larvae with shelter when discharge is high or during habitat desiccation. Lower transparency and low concentration of dissolved oxygen favor more resistant species. Chaib et al. (2011) have proved that seasonality plays a fundamental role in the composition of Chironomidae communities in the southern Mediterranean region. They have concluded that harsh climatic conditions in North-African wadis require resistance to disappearance of suitable habitats, high temperature and lentic conditions. Our study in 


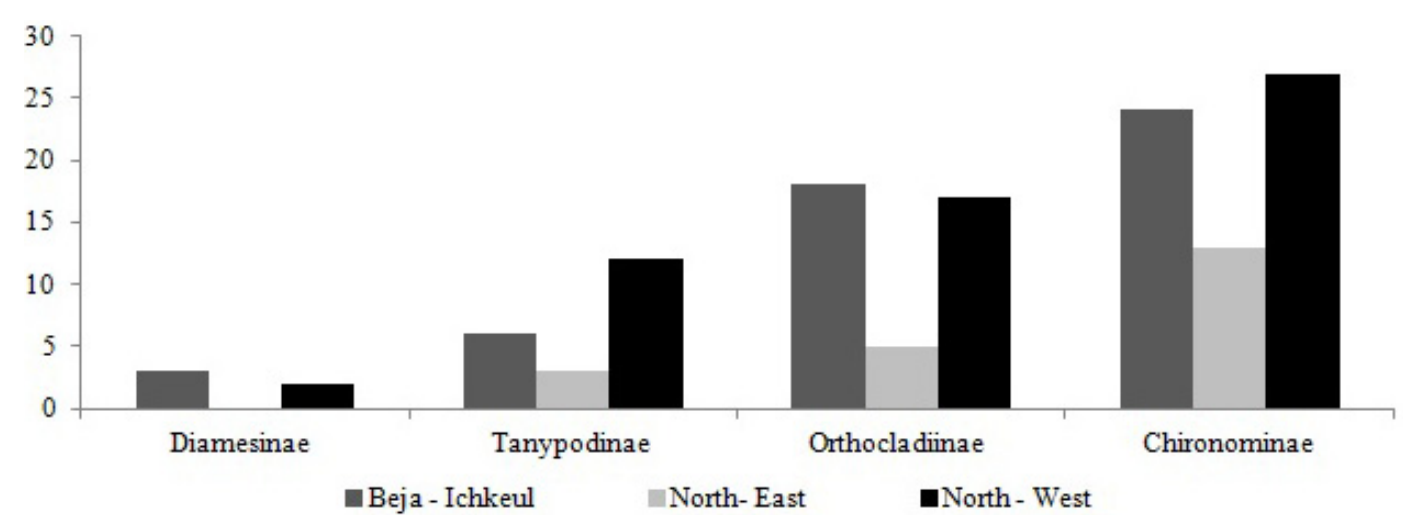

Figure 4

Total number of species within major subfamilies identified in three geographic areas of North Tunisia.

North Tunisia indicates that, in fact, lowland flowing waters are inhabited mainly by eurytopic taxa (Procladius, C. plumosus, $P$. nubeculosum-type) while in highland wadis many rheophilous, stenotopic species, requiring good water quality, such as Larsia, Rheopelopia, Phaenopsectra, Stictochironomus, occur.

Among the three study areas, only 8 taxa are relatively common and widespread (M. nebulosa, Procladius sp., O. frigidus, $R$. effusus, C. plumosus, Eukiefferiella calvescens, Dicrotendipes nervosus, Polypedilum laetum). As the North Tunisia water system is characterized by the diversity in hydrological, morphometric, geological and geographical conditions, the fauna of each region is specific and the localities with the same species recorded were situated at a distance of no more than $380 \mathrm{~km}$ from each other. In contrast to the Algerian river system (Chaib et al., 2013), for instance in the Moroccan Rif region (Kettani and Langton, 2011), Chironominae is the subfamily richest in the number of recorded species. The Cricotopus species are widespread in Algeria and Morocco (Kettani et al., 2001; Chaib et al., 2013), C. bicinctus, C. sylvestris, C. vierriensis and C. trifascia, as well as Polypedilum cultellatum, have not been, or are only rarely noted, in North Tunisia. The North-West Basin fauna stands out with the highest number of species of Orthocladiinae, Tanypodinae and Chironominae (Figure 4). Similarly to the localities in the high Atlas Mountains (Kettani et al., 2001), in the North-Eastern Basin Diamasinae are relatively well represented, while in the Ichkeul National Park Orthocladiinae are represented by a higher number of species than in the other areas. The Orthocladiinae (Eukiefferiella coerulescens, Tvetenia discoloripes, Orthocladius frigidus, Orthocladius rivulorum, Rheocricotopus effusus, Rheocricotopus fuscipes) and Tanytarsini (mainly Tanytarsus spp. and Micropsectra atrofasciata) included mostly rheophilic species (Moller Pillot, 2009; Moller Pillot and Klink, 2003). This is correlated with high frequency of orthoclads in the North-West Basin, where there are many upland and foothill streams with high slopes and a strong current (Laville, 1981). Other Chironominae (tribe Chironomini with Chironomus) are common in lentic and polluted waters such as the Béja (st. 6) and Kloufi wadis (st. 13) in the Beja Ichkeul Basin, Kasseb (st. 24), Ellil aval (st. 31), Sallen (st. 48) in the North-Western Basin and Chiba (st. 18), Méliane (st. 19) in the North-Eastern Basin site. Diamesinae occur only in the North-West Basin and the North-Eastern Basin water systems. The Diamesinae is a rather small subfamily, found mainly in high mountain areas, and cold, ultraoligotrophic, e.g. glacier fed, streams (Rossaro and Lencioni, 1999). Habitats typical for this subfamily are very scarce in Tunisia.

\section{CONCLUSIONS}

In conclusion, our studies in three different areas of North Tunisia show a high regional diversity of Chironomidae with 127 taxa recorded. Similarly to other regions of the southern 
Mediterranean Coast (Chaib et al., 2011, 2013; Kettani et al., 2001; Kettani and Langton, 2011), mainly typical Paelearctic taxa, common also in Europe, occur in North Tunisia. Its geological structure and relief provide a place for diverse habitats of temporary streams (wadi), stagnant waters and wetlands. The outspread water systems maintain rich chironomid fauna. It should be noted that the present study, if continued and intensified, should uncover even a much higher Chironomidae diversity in the Tunisian river systems. This is indicated by the rarefaction analysis (Figure 2), which shows a steep increase of taxa when any new data are added and shows no saturation at present.

\section{ACKNOWLEDGEMENTS}

We would like to thank Prof. Bruno Rossaro for verification of the material and determination, as well as to Prof. Michał Grabowski and professional translator Marta Koniarek for linguistic correction.

\section{REFERENCES}

Arab A., Lek S., Lounaci A. and Park Y.S., 2004. Spatial and temporal patterns of benthic invertebrate communities in an intermittent river (North Africa). Ann. Limnol. - Int. J. Lim., 40, 317-327.

Belaidi N., Taleb A. and Gagneur J., 2004. Composition and dynamics of hyporheic and surface fauna in a semi-arid stream in relation to the management of a polluted reservoir. Ann. Limnol. - Int. J. Lim., 40, 237-248.

Bonada N., Dolédec S. and Statzner B., 2007. Taxonomic and biological trait differences of stream macroinvertebrate communities between Mediterranean and temperate regions: implications for future climatic scenarios. Glob. Change Biol., 13, 1658-1671.

Borchardt D. and Pusch M., 2009. The Ecology of the Hyporheic Zone of Running Waters: Patterns, Processes and Bottleneck Functions. Fund. Appl. Lim., 61, 1-224.

Boumaiza M. and Laville H., 1988. Premier inventaire faunistique (Diptera, Chironomidae) des eaux courantes de la Tunisie. Ann. Limnol. - Int. J. Lim., 24, 173-181.

Brooks S.J., Langdon P.G. and Heiri O., 2007. The identification and use of Palaearctic Chironomidae larvae in palaeoecology, QRA Technical Guide No. 10. Quaternary Research Association, London, $276 \mathrm{p}$.

Chaib N., Samraoui B., Marziali L. and Rossaro B., 2011. Chironomid taxocenosis in a South Mediterranean wadi, the Kebir-East (Algeria). Studi Trent. Sci. Nat., 88, 61-75.

Chaib N., Fouzari A., Bouhala Z., Samraoui, B. and Rossaro B., 2013. Chironomid (Diptera, Chironomidae) species assemblages in northeastern Algerian hydrosystems. J. Entomol. Acar. Res., 45, 4-11.

Epler J.H., 2001. Identification Manual for the larval Chironomidae (Diptera) of North and South Carolina. A guide to the taxonomy of the midges of the southeastern United States, including Florida. Special Publication SJ2001-SP13. North Carolina Department of Environment and Natural Resources, Raleigh, NC, and St. Johns River Water Management District, Palatka, FL, 526 p.

Ferrarese U., 1983. Chironomidi, 3 (Diptera, Chironomidae: Tanypodinae) 26. In: Ruffo S. (ed.), Guide per il riconoscimento delle specie animali delle acque interne italiane. Consiglio Nazionale delle Ricerche, Stamperia, Verona, 1-67.

Ferrarese U. and Rossaro B., 1981. Chironomidi, 1 (Diptera, Chironomidae: 216 Generalità, Diamesinae, Prodiamesinae) 12. In: Ruffo S. (ed.), Guide per il riconoscimento delle specie animali delle acque interne italiane. Consiglio Nazionale delle Ricerche, Verona, Stamperia, 1-97.

Giudicelli J., Dakki M. and Dia A., 1985. Caractéristiques abiotiques et hydrobiologiques des eaux courantes méditerranéennes. Verhin. Internai. Verein. Limnol., 22, 2094-2101.

Kettani K. and Langton P.H., 2011. New data on the Chironomidae (Diptera) of the Rif (Northern Morocco). Pol. J. Entomol., 80, 587-599.

Kettani K., Ouazzani T.E. and Calle Martinez D., 2001. Mise à jour de l'inventaire des Chironomidés (Díptera) connus du Maroc. Ann. Limnol. - Int. J. Lim., 37, 323-333. 
Langton P.H., 1984. A Key to Pupal Exuviae of West Palaearctic Chironomidae, Privately published by P.H. Langton, 3, St. Felix Road, Ramsey Forty Foot, Huntingdon, Cambridgeshire, UK, 324 p.

Langton P.H. and Pinder L.C.V., 2007. Keys to the adult male Chironomidae of Britain and Ireland. Freshwater Biological Association, Ambleside, Vol. 1, 239 p., Vol. 2, 168 p.

Langton P.H. and Visser H., 2003. Chironomidae Exuviae. A Key to the Pupal Exuviae of West Palaearctic Region. ETI, Amsterdam, CD-ROM series.

Laville H., 1981. Récoltes d'exuvies nymphales de chironomides (Diptera) dans le Haut-Lot, de la source (1295m) au confluent de la Truyère (223m). Ann. Limnol. - Int. J. Lim, 17, 255-289.

Lounaci A., Brosse S., Mouloud S.A., Lounaci-Daoudi D., Mebarki N. and Thomas A., 2000a. Current knowledge of benthic macroinvertebrate diversity in Algerian stream, a species check list of the Sébaou river basin (Tizi Ouzou). Bull. Soc. Hist. Nat. Toulouse, 136, 43-55.

Lounaci A., Brosse S., Thomas A. and Lek S., 2000b. Abundance, diversity and community structure of macroinvertebrates in an Algerian stream: the Sebaou wadi. Ann. Limnol. - Int. J. Lim, 36, 123-133.

Moller Pillot H.K.M., 2009. A Key to the Larvae of the Aquatic Chironomidae of the North-west European Lowlands. Private print, not published, $77 \mathrm{p}$.

Moller Pillot H.K.M. and Klink A.G., 2003. Chironomidae larvae. Key to higher taxa and species of the lowlands of Northwestern Europe. ETI, Amsterdam, CD-ROM.

Morais M., Pinto P., Guilherme P., Rosado J. and Antunes I., 2004. Assessment of temporary streams: the robustness of metric and multimetric indices under different hydrological conditions. In: Hering D., Verdonschot P.F.M., Moog O., Sandin L. (eds.), Integrated Assessment of Running Waters in Europe. Hydrobiologia, 516, 229-249.

Nocentini A., 1985. Chironomidi, 4 (Diptera, Chironomidae: Chironominae, larvae) 29. In: Ruffo S. (ed.), Guide per il riconoscimento delle specie animali delle acque interne italiane. Consiglio Nazionale delle Ricerche, Verona, Stamperia, 1-186.

Pinto P., 1994. Cinética de colonização das comunidades de macroinvertebrados de umrio temporário do Sul de Portugal (Rio Degebe, Bacia Hidrográfica do Guadiana). Ph.D. Thesis, University of Évora, Évora, Portugal.

Rossaro B., 1982. Chironomidi, 2 (Diptera, Chironomidae: Orthocladiinae) 16:. In: Ruffo S. (ed). Guide per il Riconoscimento delle specie animali delle Acque Interne Italiane. Consiglio Nazionale delle Ricerche, Verona, Stamperia, 1-80.

Rossaro B. and Lencioni V., 1999. Analysis of relationships between chironomid species (Diptera Chironomidae) and environmental factors in an Alpine glacial stream system using a General Linear Model. Studi Trent. Sci. Nat., 76, 17-27.

Samraoui B., 2009. Seasonal ecology of Algerian Lestidae (Odonata). Int. J. Odon., 12, 383-394.

Surber E.W., 1937. Rainbow trout and bottom fauna production in one mile of stream. T. Am. Fish. Soc., $66,193-202$.

Touaylia S., Garrido J., Bejaoui M. and Boumaiza M., 2011. Altitudinal distribution of aquatic beetles in northern Tunisia: relationship between specific richness and altitude. Coleop. Bull., 65, 53-62.

Vallenduuk H.J. and Moller Pillot H.K.M., 2007. Chironomidae Larvae of the Netherlands and Adjacent Lowlands. General ecology and Tanypodinae. KNNV Publishing, Zeist, 143 p.

Wiederholm T., 1983. Chironomidae of the Holarctic region. Keys and diagnoses. Part 1. Larvae. Entomol. Scand. Supp. 19, 1-457.

Wilson R.S. and Ruse L.P., 2005. A guide to the identification of genera of chironomid pupal exuviae occurring in Britain and Ireland (including common genera from northern Europe) and their use in monitoring lotic and lentic fresh waters. The Freshwater Biological Association. The Ferry House, Far Sawrey, Ambleside, Cumbria, UK, 176 p.

Zrelli S., Boumaiza M., Bejaoui M., Gattolliat J.L. and Sartori M., 2011. New reports of mayflies (Insecta: Ephemeroptera) from Tunisia. Rev. Suisse Zool., 118, 3-10. 
Appendix I. Sampling sites within the investigated area with their coordinates, altitude (Alt) and type of substrate: Bl - Blocks, Gl - Pebbles, Gr - gravel, Sg - sand, Li - silt, Ar - clay, V - vase).

\begin{tabular}{|c|c|c|c|c|c|c|}
\hline Sites & Name of Station & Latitude N & Longitude E & $\begin{array}{c}\text { Alt. } \\
\text { (m a.s.l. })\end{array}$ & Substrate & $\begin{array}{c}\text { Stream } \\
\text { Permanace }\end{array}$ \\
\hline \multicolumn{7}{|c|}{ The basin of Beja = Ichkeul } \\
\hline St 1 & Wadi Titria & $36^{\circ} 57^{\prime} 793^{\prime \prime}$ & $08^{\circ} 57^{\prime} 894^{\prime \prime}$ & 78 & \multirow{8}{*}{$\begin{array}{c}\text { Gr. + Sg. } \\
\text { Gl. +Gr. + Sg. + Li. + Ar. } \\
\text { V. + Gr. + Ar + Li } \\
\text { Bl. + Sg. + Gl. } \\
\text { V. + Gr. + Ar. + Li. } \\
\text { V. + Gr. + Ar. + Li. } \\
\text { Sg. + Li. + V. + Gr. } \\
\text { Bl. + Sg. + Gl. }\end{array}$} & \multirow{8}{*}{\begin{tabular}{|l} 
permanent \\
permanent \\
permanent \\
permanent \\
permanent \\
permanent \\
permanent \\
permanent
\end{tabular}} \\
\hline St 2 & Wadi el Maaden & $36^{\circ} 58^{\prime} 188^{\prime \prime}$ & $09^{\circ} 05^{\prime} 100^{\prime \prime}$ & 32 & & \\
\hline St 3 & Wadi Bouzenna & $37^{\circ} 00^{\prime} 077^{\prime \prime}$ & $09^{\circ} 05^{\prime} 338^{\prime \prime}$ & 33 & & \\
\hline St 4 & Wadi Tamra & $37^{\circ} 23^{\prime} 642^{\prime \prime}$ & $09^{\circ} 06^{\prime} 245^{\prime \prime}$ & 54 & & \\
\hline St 5 & Wadi Chatt Zwaraa & $37^{\circ} 25^{\prime} 842^{\prime \prime}$ & $09^{\circ} 06^{\prime} 263^{\prime \prime}$ & 49 & & \\
\hline St 6 & Wadi Béja & $36^{\circ} 45^{\prime} 380^{\prime \prime}$ & $06^{\circ} 51^{\prime} 390^{\prime \prime}$ & 190 & & \\
\hline St 7 & Wadi Ksar Mezouar & $36^{\circ} 46^{\prime} 692^{\prime \prime}$ & $09^{\circ} 20^{\prime} 344^{\prime \prime}$ & 232 & & \\
\hline St 8 & $\begin{array}{l}\text { Wadi Joumine } \\
\text { amont }\end{array}$ & $36^{\circ} 57^{\prime} 762^{\prime \prime}$ & $09^{\circ} 31^{\prime} 478^{\prime \prime}$ & 99 & & \\
\hline St 9 & Wadi Joumine aval & $36^{\circ} 52^{\prime} 450^{\prime \prime}$ & $07^{\circ} 20^{\prime} 090^{\prime \prime}$ & 30 & \multirow{7}{*}{$\begin{array}{c}\text { V. + Ar. + Li. } \\
\text { Bl. + Sg. + Gl. + Ar. } \\
\text { Gl. + Sg. + Ar. } \\
\text { Sg. + Li. + V. + Gr. + Bl. } \\
\text { V. + Ar. + Li. } \\
\text { Sg. + Gr. + V. } \\
\text { Bl. + Gl. +Sg. + Li. }\end{array}$} & \multirow{7}{*}{$\begin{array}{l}\text { permanent } \\
\text { permanent } \\
\text { permanent } \\
\text { permanent } \\
\text { seasonal } \\
\text { permanent } \\
\text { permanent }\end{array}$} \\
\hline St 10 & Wadi El Melah & $37^{\circ} 06^{\prime} 250^{\prime \prime}$ & $07^{\circ} 12^{\prime} 100^{\prime \prime}$ & 15 & & \\
\hline St 11 & Wadi Douimis & $37^{\circ} 12^{\prime} 051^{\prime \prime}$ & $09^{\circ} 37^{\prime} 465^{\prime \prime}$ & 9 & & \\
\hline St 12 & Wadi Sejenane & $37^{\circ} 07^{\prime} 219^{\prime \prime}$ & $09^{\circ} 15^{\prime} 801^{\prime \prime}$ & 108 & & \\
\hline St 13 & Wadi El Kloufi & $37^{\circ} 11^{\prime} 985^{\prime \prime}$ & $09^{\circ} 34^{\prime} 237^{\prime \prime}$ & 13 & & \\
\hline St 14 & Wadi Ziatine & $37^{\circ} 12^{\prime} 459^{\prime \prime}$ & $09^{\circ} 13^{\prime} 976^{\prime \prime}$ & 5 & & \\
\hline St 15 & Wadi Mag & $37^{\circ} 03^{\prime} 421^{\prime \prime}$ & $09^{\circ} 13^{\prime} 820^{\prime \prime}$ & 138 & & \\
\hline \multicolumn{7}{|c|}{ The North-eastern basin 1} \\
\hline St 16 & $\mathrm{Wa}$ & $36^{\circ} 52^{\prime} 500^{\prime \prime}$ & $08^{\circ} 19^{\prime} 380^{\prime \prime}$ & 10 & \multirow{5}{*}{$\begin{array}{c}\text { Sg. + V. + Li. + Gr. } \\
\text { Sg. +V. + Gr. } \\
\text { Sg. + V. + Gl. } \\
\text { Li.+ Ar. } \\
\text { Bl.+Gl.+ Gr. }\end{array}$} & \multirow{5}{*}{\begin{tabular}{|l} 
permanent \\
permanent \\
permanent \\
permanent \\
permanent
\end{tabular}} \\
\hline St 17 & Wadi Lebna & $36^{\circ} 41^{\prime} 623^{\prime \prime}$ & '856" & 42 & & \\
\hline St 18 & Wadi Chiba & $36^{\circ} 41^{\prime} 510^{\prime \prime}$ & $08^{\circ} 26^{\prime} 150^{\prime \prime}$ & 70 & & \\
\hline St 19 & Wadi Méliane & $36^{\circ} 43^{\prime} 590^{\prime \prime}$ & $5^{\prime} 202^{\prime \prime}$ & 8 & & \\
\hline St 20 & $\begin{array}{l}\text { Wadi Zaouit } \\
\text { el Megaiez }\end{array}$ & $36^{\circ} 56^{\prime} 397^{\prime \prime}$ & '259" & 16 & & \\
\hline \multicolumn{7}{|c|}{ The Northwest basin } \\
\hline St 21 & $\begin{array}{l}\text { Wadi Medje } \\
\text { amont }\end{array}$ & $36^{\circ} 27^{\prime} 100^{\prime \prime}$ & $06^{\circ} 05^{\prime} 059^{\prime \prime}$ & 192 & Bl.+ Sg. + V. & nent \\
\hline St 22 & Wadi El Mouadjen & $36^{\circ} 55^{\prime} 676^{\prime \prime}$ & $100^{\prime \prime}$ & 760 & Bl.t+ & ent \\
\hline St 23 & Wadi Mellegue & $36^{\circ} 23^{\prime} 480^{\prime \prime}$ & $80^{\prime \prime}$ & 200 & Bl.+ Sg. + Ar. & pern \\
\hline St 24 & Wadi Kasseb & $36^{\circ} 66^{\prime} 105^{\prime \prime}$ & $06^{\circ} 67^{\prime} 575^{\prime \prime}$ & 135 & Sg. + V. & permanent \\
\hline St 25 & Wadi Mliz & $36^{\circ} 27^{\prime} 584^{\prime \prime}$ & $3^{\prime} 586^{\prime \prime}$ & 181 & Gl.+Gr.+Sg. & perr \\
\hline St 26 & $\begin{array}{l}\text { Wadi Hammam } \\
\text { Sayala }\end{array}$ & $36^{\circ} 40^{\prime} 423^{\prime \prime}$ & $3^{\prime} 581^{\prime \prime}$ & 232 & Gr.+ Li. & perr \\
\hline St 27 & Wadi Ghrib & $36^{\circ} 36^{\prime} 964^{\prime \prime}$ & $08^{\circ} 41^{\prime} 139^{\prime \prime}$ & 260 & sg. + LI + V.+ Gr. & pern \\
\hline St 28 & Wadi Ghézala & $36^{\circ} 38^{\prime} 525^{\prime \prime}$ & $06^{\circ} 21^{\prime} 590^{\prime \prime}$ & 236 & Gl. +Gr. + Sg. + Li. + Ar. & permanent \\
\hline St 29 & Wadi Labgaa & $36^{\circ} 44^{\prime} 812^{\prime \prime}$ & $08^{\circ} 44^{\prime} 350^{\prime \prime}$ & 446 & Sg. + Gr. + Ar. & pern \\
\hline St 30 & Wadi Ellil amont & $36^{\circ} 41^{\prime} 411^{\prime \prime}$ & $08^{\circ} 44^{\prime} 363^{\prime \prime}$ & 246 & Bl. + Gl. + Sg. + V. & permanent \\
\hline St 31 & Wadi Ellil aval & $36^{\circ} 41^{\prime} 244^{\prime \prime}$ & $08^{\circ} 44^{\prime} 219^{\prime \prime}$ & 237 & Bl.+ Gl.+ Gr. & permanent \\
\hline St 32 & $\begin{array}{l}\text { Wadi Chaabet } \\
\text { el Magroun }\end{array}$ & $36^{\circ} 37^{\prime} 820^{\prime \prime}$ & $06^{\circ} 21^{\prime} 890^{\prime \prime}$ & 252 & Bl.+ Gl. + Sg. & permanent \\
\hline St 33 & Wadi Saboun & $501^{\prime \prime}$ & $7^{\prime \prime}$ & 261 & G & perr \\
\hline St 34 & Wadi Barbar & $36^{\circ} 40^{\prime} 351^{\prime \prime}$ & $08^{\circ} 32^{\prime} 451^{\prime \prime}$ & 187 & Gl.+ Gr.+ Sg. & permanent \\
\hline St 35 & Wadi EdDmène & $36^{\circ} 43^{\prime} 416^{\prime \prime}$ & $08^{\circ} 41^{\prime} 474^{\prime \prime}$ & 630 & Bl. + Gl. + Sg. & permanent \\
\hline St 36 & Wadi Berbeg & $36^{\circ} 44^{\prime} 588^{\prime \prime}$ & $08^{\circ} 41^{\prime} 489^{\prime \prime}$ & 558 & Bl.+ Gl.+Gr.+Sg. & permanent \\
\hline St 37 & Wadi Lasfar & $36^{\circ} 46^{\prime} 383^{\prime \prime}$ & $08^{\circ} 46^{\prime} 348^{\prime \prime}$ & 482 & Gl.+ Gr.+ Sg. & permanent \\
\hline St 38 & Wadi Bransia & $36^{\circ} 45^{\prime} 871^{\prime \prime}$ & $08^{\circ} 45^{\prime} 091^{\prime \prime}$ & 584 & Gl.+ Gr.+ Sg. & permanent \\
\hline St 39 & Wadi Ennour & $26^{\circ} 48^{\prime} 004^{\prime \prime}$ & $08^{\circ} 39^{\prime} 539^{\prime \prime}$ & 394 & Gl.+ Gr.+ Sg. & permanent \\
\hline St 40 & Wadi Ain Gnaa & $36^{\circ} 33^{\prime} 533^{\prime \prime}$ & $08^{\circ} 47^{\prime} 252^{\prime \prime}$ & 137 & Li. & seasonal \\
\hline St 41 & Wadi Mrig & $36^{\circ} 45^{\prime} 605^{\prime \prime}$ & $08^{\circ} 41^{\prime} 270^{\prime \prime}$ & 577 & Gr.+ Li. & seasonal \\
\hline St 42 & Wadi El Kébir & $36^{\circ} 55^{\prime} 252^{\prime \prime}$ & $08^{\circ} 45^{\prime} 252^{\prime \prime}$ & 10 & V. + Li. + Gl. + Ar. & permanent \\
\hline St 43 & $\begin{array}{l}\text { Wadi El Amor } \\
\text { amont }\end{array}$ & $36^{\circ} 54^{\prime} 255^{\prime \prime}$ & $08^{\circ} 44^{\prime} 512^{\prime \prime}$ & 30 & Bl. + Gl. + Sg. & permanent \\
\hline St 44 & Wadi El Amor aval & $36^{\circ} 55^{\prime} 303^{\prime \prime}$ & $08^{\circ} 44^{\prime} 425^{\prime \prime}$ & 14 & Sg. + Li. & permanent \\
\hline St 45 & Wadi Rennagha & $36^{\circ} 51^{\prime} 620^{\prime \prime}$ & $08^{\circ} 43^{\prime} 245^{\prime \prime}$ & 62 & Bl. + Gl. + Sg. + Li. & permanent \\
\hline St 46 & Wadi Bouterfes & $36^{\circ} 55^{\prime} 251^{\prime \prime}$ & $08^{\circ} 50^{\prime} 579^{\prime \prime}$ & 24 & Bl. + Gl. + Sg. + Li. & permanent \\
\hline St 47 & Wadi Mlila & $36^{\circ} 46^{\prime} 172^{\prime \prime}$ & $08^{\circ} 34^{\prime} 459^{\prime \prime}$ & 150 & Bl.+ Gl.+ Gr.+ Li. & permanent \\
\hline St 48 & Wadi Sallen & $36^{\circ} 46^{\prime} 123^{\prime \prime}$ & $08^{\circ} 34^{\prime} 491^{\prime \prime}$ & 410 & Bl.+ Gl.+ Gr.+ Li. & permanent \\
\hline
\end{tabular}




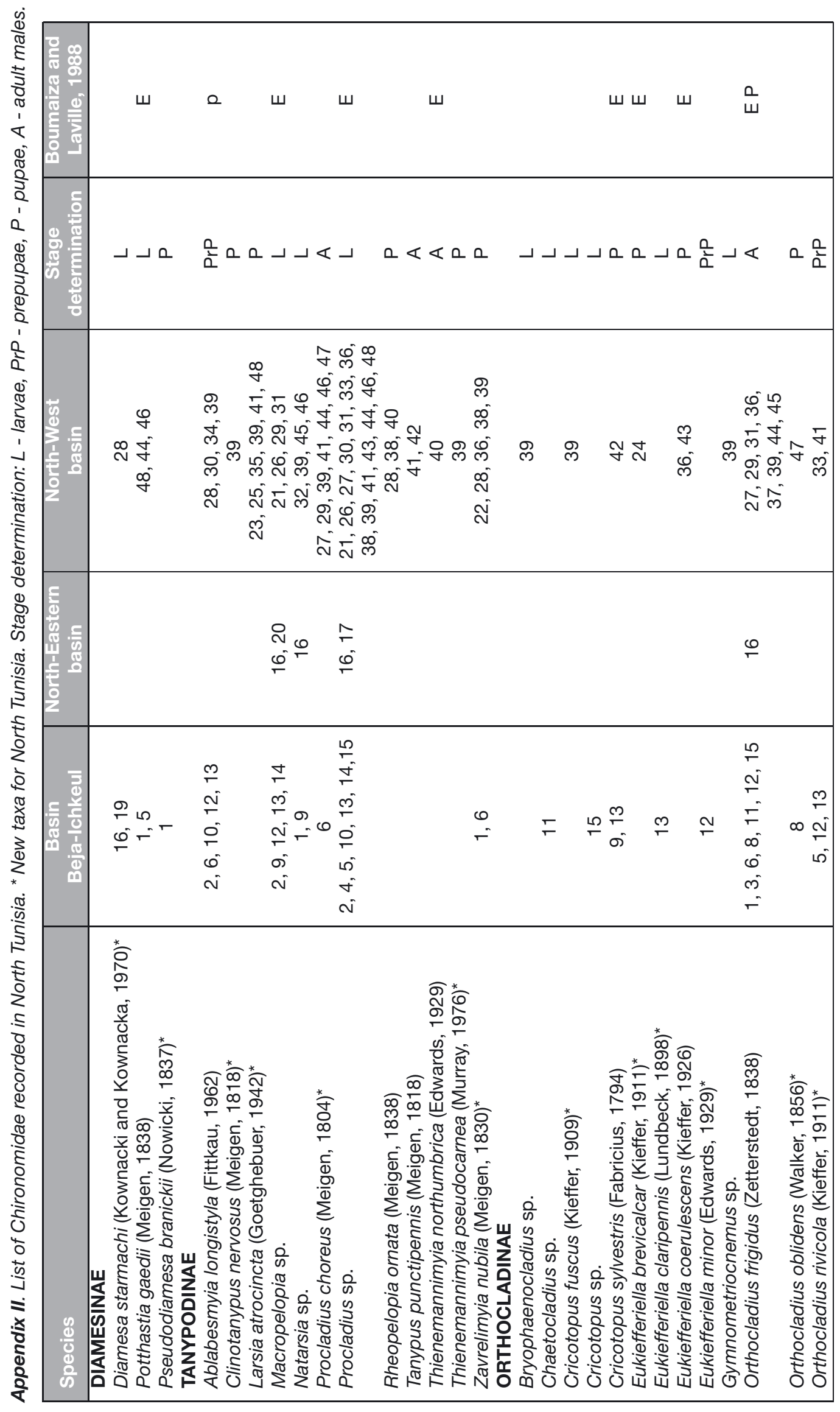




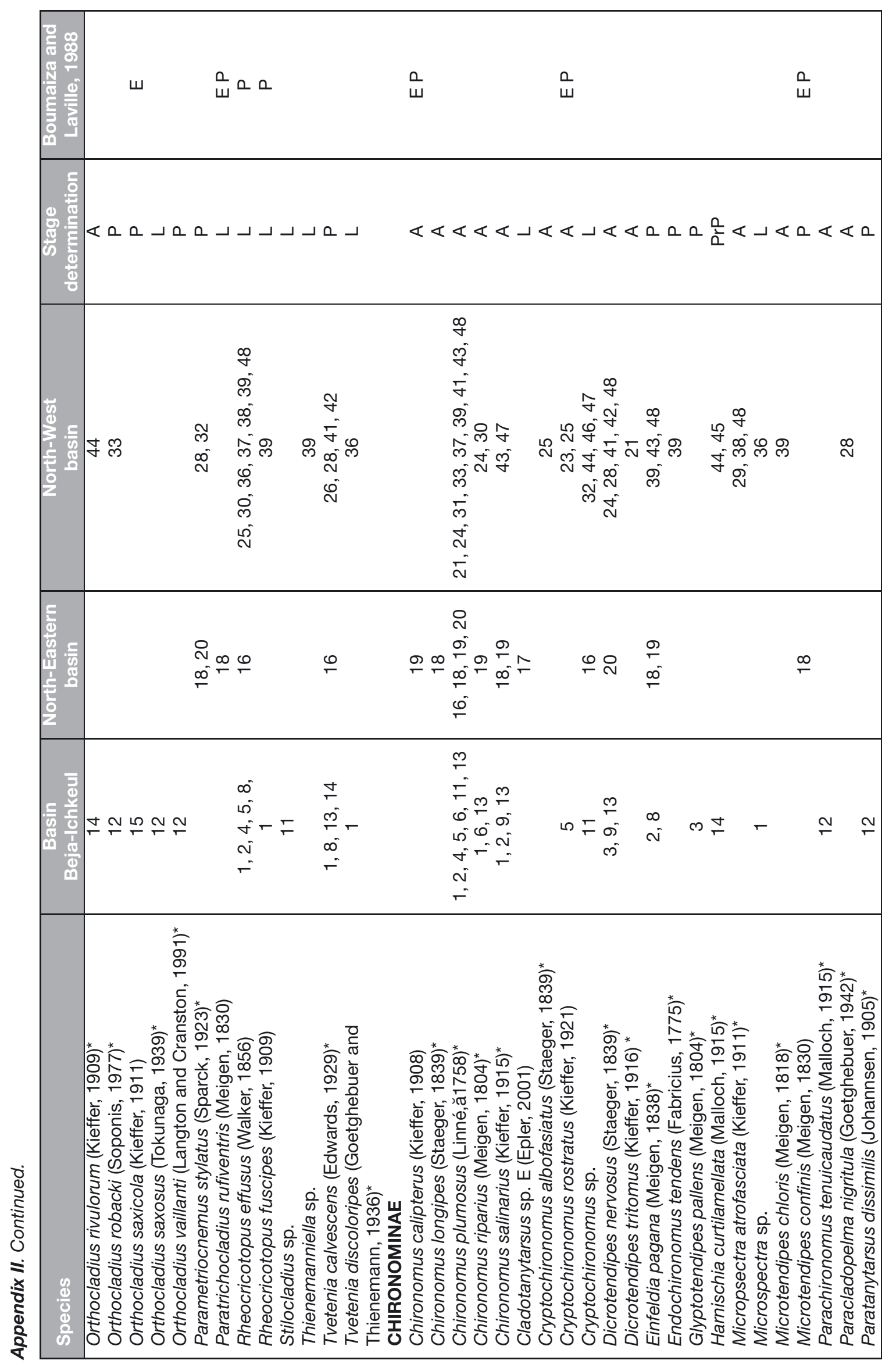




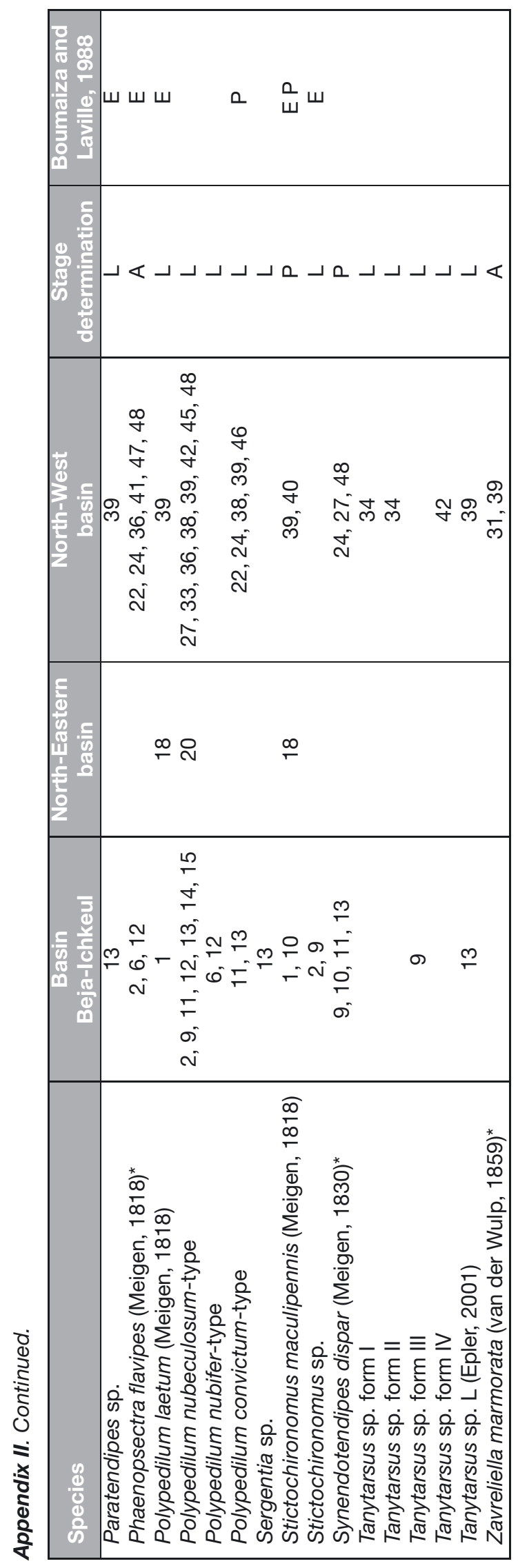

